PENELITIAN

\title{
Perbandingan Penggunaan Triamcinolone Acetonide Dan Lidocaine Pada Pipa Endotrakea Terhadap Angka Kejadian Nyeri Tenggorok Pasca Intubasi Pada Anestesi Umum
}

\section{Comparison Between Applied Endotracheal With Triamcinolone Acetonide And Lidocaine On Sore Throat Incidence Post General Anesthesia Intubation}

Erwin Ferdian $\bigotimes^{*}$, Soenarjo**, Uripno Budiono**

*RSIA Aulia, Lenteng Agung, Jakarta Selatan

**Bagian Anestesi dan Terapi Intensif Fakultas Kedokteran Universitas Diponegoro/ RSUP Dr. Kariadi Semarang.

$\triangle$ Korespondensi/ Correspondence: ez_dian@yahoo.com

\section{ABSTRACT}

Background: One of complications after intubation (endotracheal tube insertion) is post operative post operative because of tracheal mucous damage. Triamcinolone acetonide gel consists of corticosteroid, not only as lubrication agent but also antiinflammation effects.

Objectives: to compare the insidens sore throat post intubation using triamcinolone acetonide compare to lidocaine jelly within endotracheal tube.

Methods: 58 patients undergo elective surgery with general anaesthesia in Dr. Karyadi National Hospital, which applied to inclusion criteria, divided into 2 randomized group. Induction using propofol $2 \mathrm{mg} / \mathrm{kg}$ body weight $\mathrm{IV}$, rocuronium 0,6 $\mathrm{mg} / \mathrm{kg}$ body weight IV and fentanyl $1 \mathrm{mcg} / \mathrm{kg}$ body weight IV, intubate with high volume low pressure non kinking endotracheal tube number 7,0 for female patients and number 7,5 for male patients. The first group (K1) was given triamcinolone acetonide in oral based 0,1\% within endotrachea, the second group(K2) was given lidocaine jelly $0,5 \% 15 \mathrm{~cm}$ distal endotracheal tube. Cuffed then inflated with $20 \mathrm{cc}$ air until no leakage. Maintenance using anaesthetic gas isoflurane 1-1,5\%: O2 50\%: $\mathrm{N} 2 \mathrm{O} 50 \%$, and intermitten rocuronium muscle relaxant. $30 \mathrm{mg}$ ketorolac and $2 \mathrm{mg} / \mathrm{kg}$ body weight intravenous tramadol were given as analgetic. Extubation performed after patient fully awake, and we did observations in sore throat insidens in 1, 6, and 24 hours post extubation.

Results: The insidens of sore throat after endotracheal intubation in first group compare to second group are smaller

Conclusions: Triamcinolon acetonide gel is better than Lidocaine gel in reducing post operative sore throat incidence with general anaesthesia. 
Keywords: triamcinolone acetonide, lidocaine gel, endotracheal intubation, sore throat complications.

\section{ABSTRAK}

Latar Belakang : Salah satu komplikasi pemasangan pipa endotrakea adalah nyeri tenggorok paska operasi akibat kerusakan mukosa trakhea. Triamcinolone acetonide gel mengandung kortikosteroid disamping dapat sebagai agen lubrikasi juga mempunyai efek anti inflamasi.

Tujuan : Membandingkan efek lubrikasi pipa endotrakea dengan triamcinolone acetonide gel dan lidocaine jelly terhadap angka kejadian nyeri tenggorok paska intubasi.

Metode : 58 pasien yang menjalani operasi elektif dengan anestesi umum di RSUP Dr.Kariadi Semarang dan memenuhi kriteria inklusi dibagi secara acak menjadi 2 kelompok. Induksi menggunakan propofol $2 \mathrm{mg} / \mathrm{kgBB}$ iv, rokuronium 0,6 $\mathrm{mg} / \mathrm{kgBB}$ iv dan fentanyl $1 \mathrm{mcg} / \mathrm{kgBB}$ iv kemudian dilakukan intubasi dilakukan intubasi dengan pipa endotrakea high volume low pressure non kinking dengan ukuran 7.0 untuk perempuan dan 7,5 untuk laki-laki. Kelompok 1 (K1) diberikan triamcinolone acetonide in orabase 0,1\% pada pipa endotrakea, kelompok 2 (K2) diberikan Lidocaine Jelly masing-masing diberikan 0,5 cc dilubrikasikan pada pipa endotrakea sepanjang $15 \mathrm{~cm}$ dari ujung distal. Selanjutnya cuff dikembangkan dengan udara dalam spuit 20 cc sampai tidak terdengar kebocoran udara napas. Rumatan anestesi dengan isofluran 1-1,5\% dalam $\mathrm{O} 2$ dan $\mathrm{N}_{2} \mathrm{O}$ $50 \%$ dan pelumpuh otot rokuronium intermiten. Analgetik diberikan ketorolak $30 \mathrm{mg}$ dan tramadol $2 \mathrm{mg} / \mathrm{kgBB} \mathrm{iv}$. Selesai operasi, ekstubasi pipa endotrakea dilakukan saat pasien sudah sadar. Dilakukan observasi nyeri tenggorokan 1 jam, 6 jam dan 24 jam setelah ekstubasi.

Hasil : Angka kejadian nyeri tenggorok paska intubasi endotrakea pada kelompok 1 lebih rendah dibandingkan pada kelompok 2.

Kesimpulan : Triamcinolon acetonide jelly lebih baik dibanding lidocaine jelly dalam mengurangi nyeri tenggorok paska anestesi umum dengan intubasi.

Kata Kunci : Triamcinolone acetonide, Lidocaine jelly, pipa endotrakea, nyeri tenggorokan

\section{PENDAHULUAN}

Nyeri tenggorok merupakan masalah yang sering terjadi paska operasi pada pasien yang mendapat anestesi umum dengan intubasi

endotrakheal tube, meskipun pasien telah mendapat analgetik. Insiden nyeri tenggorokan bervariasi antara 14,4 - 
$50 \%{ }^{1}$ dari 5264 pasien ambulatory surgery, $12,1 \%$ diantaranya mengalami nyeri tenggorok, angka tertinggi kejadian $(45,4 \%)$ didapat pada pasien yang mendapat endotrakheal tube. ${ }^{2}$

Beberapa faktor berpengaruh pada nyeri tenggorok paska anestesi dengan intubasi endotrakheal tube antara lain wanita lebih sering dari lakilaki, ukuran dan jenis endotrakheal tube, ukuran dan jenis cuff endotrakheal, lamanya pemakaian endotrakheal tube, sukar tidaknya proses intubasi, pergeseran endotrakheal tube selama pembedahan, berlebihan tidaknya suction lendir pada waktu ekstubasi dan mulus tidaknya proses ekstubasi. ${ }^{1}$

Sebagai penyebab nyeri tenggorok adalah terjadinya iritasi lokal dan inflamasi pada jalan nafas atau trauma pada mukosa jalan nafas akibat pemasangan endotrakheal tube. ${ }^{1,3}$ Usaha untuk mengurangi nyeri tenggorok dilakukan dengan cara mengurangi trauma pada jalan nafas antara lain: menggunakan endotrakheal tube dengan ukuran lebih kecil, intubasi dilakukan setelah relaksasi penuh, dan dilakukan dengan hati-hati, mengurangi tekanan intracuff, melumasi endotrakheal tube dengan jelly, tidak melakukan suction jalan nafas berlebihan. $^{1}$

Lidokain diduga dapat mengatasi nyeri tenggorok paska intubasi karena berkhasiat anestesi lokal, dan menyebabkan vasodilatasi. Karena itu dilakukan penelitian- penelitian menggunakan lidokain untuk mengatasi nyeri tenggorok, hasilnya bervariasi.

Obat-obat golongan steroid berkhasiat antiinflamasi, diduga dapat mengatasi nyeri tenggorok paska intubasi, karena nyeri tenggorok tersebut merupakan proses inflamasi. Beberapa penelitian penggunaan steroid untuk mengatasi nyeri tenggorok pada intubasi antara lain dengan dexametason intravena, hidrokortison krim $1 \%$, betametason jel dan triamsinolon.

Triamsinolon asetonid mempunyai keunggulan dibanding steroid lain karena potensinya lemah tetapi mempunyai komponen asetonid yang memudahkan penetrasi ke jaringan dan menguntungkan bila dipakai secara topical. ${ }^{4}$ Dengan potensi yang lemah, efek yang merugikan dari steroid seperti terjadinya infeksi, kandidiasis, mulut dan tenggorokan kering bisa dikurangi. Triamsinolon asetonid memakai pengawet metilparaben dan propil paraben yang bersifat antibakteri dan antijamur, dan sudah biasa dipakai untuk pengawet makanan, minuman, dan obat-obatan. ${ }^{5}$

Dari penelitian Park dkk, didapat bahwa triamsinolon jelly yang dioleskan pada endotrakheal tube mengurangi terjadinya nyeri tenggorok paska operasi dengan intubasi. Tetapi penelitian tersebut membandingkan dengan endotrakheal tube yang diolesi klorheksidin jelly, suatu bahan yang bersifat iritatif pada mukosa dan ini mungkin akan meningkatkan terjadinya 
Tabel 1. Hasil Penelitian

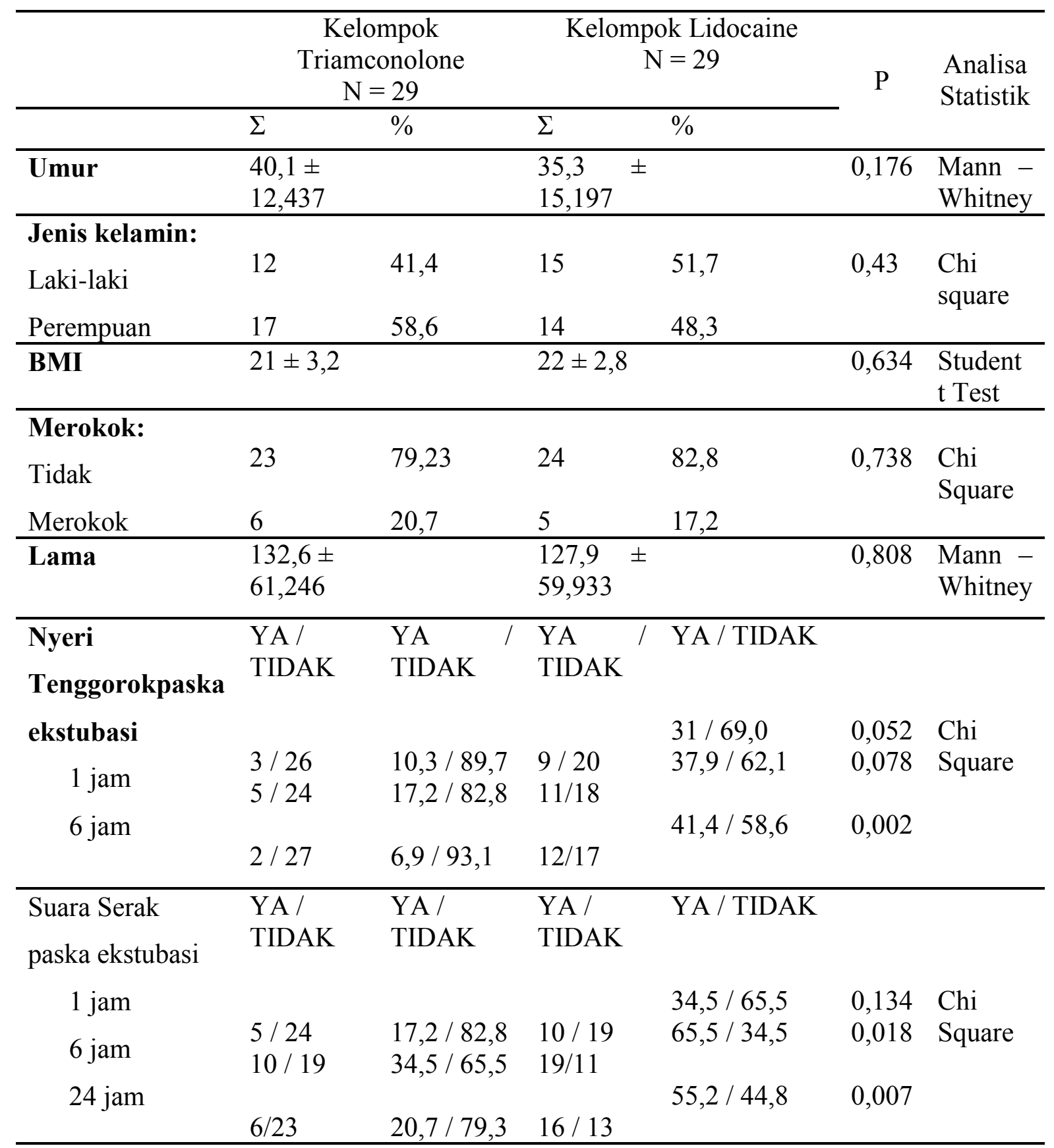


nyeri tenggorok. Selain itu, pada penelitian tersebut juga digunakan dexametason intravena yang juga termasuk steroid. ${ }^{6}$

Pada penelitian ini dibandingkan penggunaan triamsinolon asetonid jelly dan lidokain jelly yang dioleskan pada pipa endotrakheal terhadap nyeri tenggorok paska intubasi pada anestesi umum.

\section{METODE}

Penelitian ini berbentuk NonRandomized Clinical Controlled Trial. Dalam rancangan eksperimental, pengukuran dan observasi dilakukan diawal dan setelah perlakuan.Tempat penelitian adalah Instalasi Bedah Sentral RSUP Dr. Kariadi Semarang.

Pasien yang menjalani operasi elektif dengan anestesi umum di Instalasi Bedah Sentral RSUP Dr. Kariadi Semarang yang memenuhi kriteria inklusi dan eksklusi, kemudian dilakukan consecutive sampling dibagi menjadi dua kelompok berdasarkan tabel acak yang sudah dibuat. Peneliti tidak mengetahui pasien berikutnya (double blind).

Kedua kelompok penelitian ini diberi perlakuan yang berbeda, kelompok 1 (K1) : diberikan triamcinolone acetonide topikal pada pipa endotrakea dan kelompok 2 (K2) : diberikan xylocaine jelly pada pipa endotrakea.

Kriteria Inklusi adalah usia $15-65$ tahun, status fisik ASA I - II, lama operasi $>60$ menit, skor Mallampati I II, pasien yang menjalani operasi pada daerah kepala dan leher, setuju dilakukan penelitian. Sedangkan kriteria eksklusi adalah pasien dengan riwayat infeksi saluran pernafasan dan nyeri tenggorokan pre operasi, penggunaan analgetik atau steroid pre operasi, pasien dengan risiko terkena infeksi rongga mulut, pasien yang memerlukan lebih dari satu kali usaha intubasi, pasien yang terpasang pipa nasogastrik.

Perhitungan jumlah sampel untuk penelitian ini menggunakan rumus besar sampel dengan uji hipotesis terhadap dua proporsi didapatkan $\mathrm{n} 1=\mathrm{n} 2=28,7$ orang $=29$ orang sehingga besar sampel yang dibutuhkan sebanyak 58 orang.

Pasien yang memenuhi syarat dipuasakan selama 6 jam sebelum operasi dan dipasang infus dengan cairan kristaloid. Premedikasi diberikan pada saat pasien berada dalam kamar operasi. Premedikasi menggunakan midazolam $0,05 \mathrm{mg} / \mathrm{kgBB}$.

Induksi menggunakan propofol $2 \mathrm{mg} / \mathrm{kgBB}$ iv, rocuronium $0,6 \mathrm{mg} /$ $\mathrm{kgBB}$ iv dan fentanyl $1 \mathrm{mg} / \mathrm{kgBB}$ iv, kemudian dilakukan intubasi dengan pipa endotrakea high volume low pressure dengan ukuran 7.0 untuk perempuan dan 7,5 untuk laki-laki. Kelompok 1 (K1) diberikan triamcinolone acetonide in orabase 0,1 $\%$ pada pipa endotrakea, kelompok 2 (K2) diberikan xylocaine jelly pada pipa endotrakea masing-masing diberikan 0,5 cc dilubrikasikan pada pipa endotrakea sepanjang $15 \mathrm{~cm}$ dari ujung distal. Selanjutnya cuff 
dikembangkan dengan udara dalam spuit 20 cc sampai tidak terdengar kebocoran udara napas.

Rumatan anestesi dengan isofluran 1-1,5\% dalam $\mathrm{O} 2$ dan $\mathrm{N}_{2} \mathrm{O}$ $50 \%$ dan pelumpuh otot rocuronium intermiten. Analgetik diberikan ketorolak $30 \mathrm{mg}$ dan tramadol $2 \mathrm{mg} /$ $\mathrm{kgBB}$ iv.

Setelah selesai operasi, agent anestesi dihentikan, pasien dipertahankan napas spontan dengan $\mathrm{O}_{2}$ $100 \%$. Ekstubasi pipa endotrakea dilakukan jika pasien bernapas spontan adekuat, pasien mampu mengikuti perintah verbal (membuka mata atau tangan menggenggam) atau kecenderungan untuk mencabut sendiri pipa endotrakea.

Satu jam, 6 jam dan 24 jam paska ekstubasi, dilakukan pengamatan dan wawancara terhadap pasien secara cermat tentang adanya nyeri tenggorokan yang dinilai dengan menggunakan sistem grading dengan nilai 0 sampai dengan 3 dan nilai Visual Analogue Scale (VAS). ${ }^{9}$

Nilai dari parameter tersebut adalah nyeri tenggorokan: 0 tidak ada nyeri tenggorokan, 1 : ringan (lebih ringan daripada nyeri pada radang tenggorokan), 2 : sedang (nyeri seperti pada radang tenggorokan), 3 : berat (nyeri lebih dari radang tenggorokan). Parameter suara serak: 0 : tidak ada suara serak, 1 : ringan (tidak ada suara serak pada saat wawancara tetapi pernah ada sebelum wawancara), 2 : sedang (hanya dirasakan oleh pasien), 3 : berat (dapat diketahui oleh pewawancara pada saat wawancara). Parameter batuk: 0 : tidak ada batuk, 1 : ringan (lebih ringan daripada batuk pada radang tenggorokan), 2 : sedang (batuk seperti pada radang tenggorokan), 3 : berat (batuk lebih dari radang tenggorokan).

Data dikumpulkan dan dicatat dalam lembar khusus penelitian yang telah disediakan serta diolah dengan komputer menggunakan program spss 18 dan dinyatakan rerata \pm simpang baku (mean \pm SD) disertai kisaran (range). Uji statistik menggunakan student $\mathrm{t}$ test dan chi square dengan derajat kemaknaan $p<0,05$. Penyajian data dalam bentuk grafik dan tabel.

\section{HASIL}

Didapat 58 sampel penelitian yang terdiri dari 29 sampel dari kelompok yang mendapat Triamcinolone acetonide dan 29 sampel dari kelompok yang mendapat Lidocaine Jelly pada ETT.

Dari data umur, jenis kelamin, macam operasi, riwayat merokok, dan lama terintubasi berbeda tidak bermakna, sehingga kedua kelompok dianggap homogen dan dapat dibandingkan dalam suatu penelitian.

Angka nyeri tenggorok pada kelompok Triamcinolone acetonide selalu lebih rendah dibanding kelompok Lidocaine, baik pada 1 jam $(3 / 10,3 \%$ : 9/31\%), 6 jam (5/17,2\%: 11/37,9\%), dan 24 jam paska ekstubasi (2/6,9\% : $12 / 41,4 \%$ ). Perbedaan ini bermakna pada 24 jam paska ekstubasi.

Demikian juga pada suara serak 
baik 1 jam, 6 jam, dan 24 jam paska ekstubasi lebih rendah pada kelompok Triamcinolone acetonide dan perbedaan tersebut bermakna pada 6 jam dan 24 jam paska ekstubasi.

Angka kejadian batuk kelompok Triamcinolone acetonide lebih rendah dan bermakna dibanding kelompok Lidocaine pada 6 jam dan 24 jam paska ekstubasi. Tetapi pada 1 jam paska ekstubasi, kelompok Triamcinolone acetonide lebih tinggi dibanding kelompok Lidocaine, tetapi tidak bermakna.

\section{PEMBAHASAN}

Dari penelitian ini didapat bahwa angka nyeri tenggorok pada kelompok triamcinolone lebih rendah baik pada satu jam, enam jam, dan dua puluh empat jam paska ekstubasi dibanding kelompok lidokain, perbedaan ini bermakna pada dua puluh empat jam paska ekstubasi (6,9\%: 41,4\%). Dari penelitian ini juga didapat insiden batuk dan suara serak lebih rendah pada kelompok triamcinolone dibanding kelompok lidokain.

Hal ini sesuai dengan penelitian Selvaraj dan Dhanpal bahwa steroid gel lebih baik dibanding lidokain gel dalam mengatasi nyeri tenggorok, batuk, dan suara serak. $^{7}$ Demikian juga pada penelitian Park dkk angka nyeri tenggorok kelompok yang menggunakan triamcinolone yang dioleskan pada endotracheal tube lebih rendah dibanding kelompok yang diolesi chlorhexidine. Perbedaan ini bermakna baik pada satu jam, enam jam, dan dua puluh empat jam paska ekstubasi. ${ }^{6}$ Perbedaan hasil penelitian Park dan penelitian ini mungkin karena Park menggunakan chlorhexidine yang bersifat iritatif sebagai pembanding, selain itu Park juga menambahkandeksametason intravena, sedang penelitian ini menggunakan lidokain sebagai pembanding dan tidak menggunakan steroid lain.

Sumathi dkk mendapatkan angka nyeri tenggorok pada kelompok endotracheal tube yang diolesi kortikosteroid lebih rendah dibanding kelompok yang diolesi lidokain gel maupun kelompok kontrol, perbedaan ini bermakna baik pada satu jam, enam jam, dan dua puluh empat jam paska anestesi. ${ }^{8}$ Perbedaan dengan penelitian ini mungkin karena Sumathi menggunakan betamethasone gel yang setara dengan $4 \mathrm{mg}$ prednison, sedangkan penelitian ini menggunakan triamcinolone yang setara dengan 0,4 mg prednisone.

Kazemi dan Amini mendapatkan angka dan beratnya nyeri tenggorok yang lebih rendah pada kelompok yang menggunakan endotracheal tube yang diolesi dengan $0,05 \%$ bethametasone dibandingkan kelompok yang menggunakan endotracheal tube yang diolesi K-Y gel. ${ }^{9}$

Ayoub dkk mendapatkan nyeri tenggorok yang lebih rendah pada kelompok yang mendapat betamethasone $\quad 0,05 \%$ dibandingkan yang mendapat chlorhexidine. Ayoub menduga bahwa penggunaan 
betamethasone pada bagian endotracheal tube yang bersentuhan dengan dinding posterior faring, pita suara dan trakhea mampu mengurangi udem dan peradangan. ${ }^{3}$

\section{Keberhasilan}

penggunaan steroid untuk mengurangi nyeri tenggorok paska intubasi memperkuat dugaan bahwa nyeri tenggorok merupakan akibat dari proses inflamasi.

Dalam hal ini kortikosteroid mengurangi sintesa sitokin dan mediator-mediator inflamasi yang lain, seperti prostaglandin dan leukotrin dengan menghambat pospolipase A2 dan siklooksigenase2 pada inflamasi. Aksi dari kortikostreoid topikal efektif menghambat inflamasi dan ulserasi pada mukosa. ${ }^{10,11}$

Meskipun demikian, pemberian kortikosteroid topical tidak selalu menghasilkan angka nyeri tenggorok yang lebih rendah. Stride dkk, mengoleskan 1\% hidrokortison krim pada endotracheal tube ternyata tidak efektif mengurangi nyeri tenggorok, padahal steroid yang dioleskan setara dengan 5,2 - 7,7 $\mathrm{mg}$ prednisone. ${ }^{12}$ Sedangkan betamethasone yang dipakai Sumathi hanya setara dengan $4 \mathrm{mg}$ prednison $^{8}$ dan Ayoub setara dengan 3 mg prednison ${ }^{3}$ keduanya efektif mengurangi nyeri tenggorok. Sebagai penyabab muingkin Stride hanya mengoleskan hidrokortison sepanjang 5 $\mathrm{cm}$ diatas cuff sedangkan penelitian lain sampai $15 \mathrm{~cm}$.

Kortikosteroid intravena juga dapat mengurangi nyeri tenggorok paska operasi. Hal ini terlihat pada penelitian Bagchi dkk, 0,2 mg/kgBB dexamethasone intravena. ${ }^{13}$ Thomas dan Beevi menggunakan dexamethasone $8 \mathrm{mg}$ iv. ${ }^{14}$ Park dkk menggunakan dexamethasone $0,2 \mathrm{mg} /$ $\mathrm{kgBB}$ pada intubasi endotracheal tube double lumen. ${ }^{15}$ Ketiga penelitian ini membuktikan bahwa dexamethasone iv dapat mengurangi angka nyeri tenggorok. Tetapi hasil penelitian Ruangsin membuktikan bahwa dexamethasone iv tidak efektif mengurangi nyeri tenggorok paska anestesi umum dengan endotracheal tube baik dengan dosis $4 \mathrm{mg}$ maupun 8 mg. ${ }^{16}$ Sementara Tabari dkk membuktikan bahwa dexamethasone iv maupun betamethasone gel yang dioleskan pada endotracheal tube sama efektif mencegah nyeri tenggorok paska anestesi dengan intubasi. ${ }^{17}$

Pada penelitian ini nyeri tenggorok pada kelompok lidokain mencapai $41,4 \%$ pada dua puluh empat jam paska ekstubasi, sehingga setara dengan angka kejadian nyeri tenggorok paska operasi pada pasien yang mendapat anestesi umum dengan intubasi yang berkisar antara 14,4 $50 \% .{ }^{1}$ Tingginya angka nyeri tenggorok pada penelitian ini mungkin karena sampel diambil dari operasi daerah leher dan kepala. Penelitian ini juga mempunyai kekukarangan karena tidak mengambil sampel untuk kelompok kontrol, sehingga kelompok lidokain topical tidak bisa dibandingkan dengan kelompok kontrol atau manfaatnya tidak bisa diketahui.

Meskipun demikian bila 
dibanding dengan angka nyeri tenggorok paska operasi tyroid yang mencapai $80 \%{ }^{18}$ atau pasca operasi timpanoplastik yang mencapai $57,1 \%$ bagi yang mendapat dexamethasone pre operatif dan $62,9 \%$ bagi yang mendapat dexamethasone post operatif ${ }^{19}$ angka nyeri tenggorok kelompok lidokain pada penelitian ini masih lebih rendah.

Dari penelitian Nurdin dkk didapat bahwa akibat intubasi endotrakheal, bagian mukosa yang tertekan oleh endotracheal tubeakan mengalami iskemia yang selanjutnya diikuti dengan inflamasi. ${ }^{20}$ Lidokain selain mempunyai efek analgesi juga mempunyai efek vasodilatasi. Efek Vasodilatasi akan mengatasi iskemia pada mukosa yang tertekan endotracheal tube. Mekanisme vasodilatasi ini akibat halangan pada kanal natrium pada dosis lidokain yang sesuai. ${ }^{21}$ Efek vasodilatasi lidokain juga dimediasi oleh pelepasan nitric oxide dari endotel vaskuler. ${ }^{22}$

Atas dasar tersebut seharusnya lidokain topikal dapat mencegah iskemia mukosa yang selanjutnya dapat mencegah inflamasi sehingga angka nyeri tenggorok dapat dikurangi. Tetapi dari penelitian Herlevsen didapat bahwa angka nyeri tenggorok paska operasi antara kelompok yang mendapat lidokain spray tidak berbeda dengan kelompok yang tidak mendapat lidokain spray. ${ }^{23}$ Dari penelitian Maruyama dkk didapat bahwa penggunaan lidokain spray meningkatkan angka nyeri tenggorok, sehingga merekomendasikan untuk tidak menggunakan lidokain spray pada intubasi endotracheal. ${ }^{24}$ Selanjutnya dari penelitian Hara dan Maruyama dapat disimpulkan bahwa nyeri tenggorok paska operasi dengan lidokain spray disebabkan oleh menthol dan ethanol sebagai zat adiktif lidokain spray. $^{25}$

Dari penelitian Doukumo dkk didapat bahwa K-Y jelly lebih efektif dibanding lidokain gel dalam mengatasi nyeri tenggorok. ${ }^{26}$ Dari penelitian Navarro dkk, lidokain yang dimasukkan dalam cuff endotracheal tube dapat mengurangi nyeri tenggorok paska anestesi dengan endotracheal tube $^{27}$ karena lidokain dapat berdifusi keluar dari cuff menuju ke mukosa. Hal ini terbukti dari penelitian Huang bahwa lidokain dapat berdifusi keluar dari cuff. ${ }^{28}$ Dari penelitian Soltani dkk didapat bahwa baik lidokain intravena atau lidokain yang dimasukkan dalam cuff dapat mengurangi nyeri tenggorok dan batuk. $^{29}$ Dari pemeriksaan bronkoskopi Abbasi dkk membuktikan bahwa lidokain dalam cuff mengurangi kerusakan mukosa akibat intubasi. ${ }^{30}$

Pada penelitian ini tingginya angka nyeri tenggorok pada kelompok yang mendapat lidokain gel mungkin karena durasi pemakaian endotracheal tube (lebih dari 2 jam) melebihi duration of action lidokain gel. Sementara itu dari penelitian-penelitian lain yang menggunakan lidokain yang dimasukkan dalam cuff mungkin karena lidokain tidak berdifusi sekaligus dari dalam cuff menuju ke mukosa, sehingga dalam waktu tertentu 
masih terjadi difusi lidokain dengan akibat pengaruh lidokain pada mukosa pada kurun waktu tertentu masih terjadi, sementara bagi yang diberikan secara topical sudah habis pengaruhnya.

\section{SIMPULAN}

Dari penelitian ini angka nyeri tenggorok paska intubasi endotrakea pada kelompok 1 yang diberikan Triamcinolon acetonid lebih rendah dibandingkan pada kelompok 2 yang diberikan lidocaine jelly, sehingga dapat disimpulkan bahwa Triamcinolon acetonide jelly lebih baik dibanding lidocaine jelly dalam mengurangi nyeri tenggorok paska anestesi umum dengan intubasi.

\section{DAFTAR PUSTAKA}

1. Mc Hardy FE, Chung F. Postoperative sore throat: cause, prevention and treatment. Anaesthesia 1999; 54:444-53

2. Higgins PP, Chung F, Mezei G. Postoperative sore throat after ambulatory surgery. Br J Anaesth 2002:88:582-4

3. Ayoub Mc, Ghobashy A, Koch ME, Mc Grimley L, Pascale V, Qadir S, dkk. Widespread application of typical steroid to decrease sore throat, hoarseness, and cough after tracheal intubation. Anesth Analg 1998:87:714-6

4. Katz M, Gans EH. Topical corticosteroids, structure-activity and the glucocorticoid receptor: discovery and development - a process of planned serendipity. J Pharm Sci 2008:97:2936-47

5. Matysova L, Hajkova R, Sicha J, Solich P. Determination of methyl paraben, propyl paraben, triamcinolone acetonide and its degradation product in atopical cream by RP-HPLC. Anal Bioanal Chem 2003:376:440-3

6. Park SY, Kim SH, Lee SJ, Chae WS, Jin HC, Lee JS dkk. Application of triamcinolone acetonide paste to the endotracheal tube reduces postoperative sore throat: a randomized controlled trial. Can J Anaesth 2011:58:436-442

7. Selvaraj T, Dhanpal R. Evaluation of the application of topical steroids on the endotracheal tube in decreasing postoperative sore throat. J Anaesthesiol Clin Pharmacol 2002:18:167-70

8. Sumathi PA, Shenoy T, Ambareesha M, Krishna HM, Controlled Comparison between betamethasone gel and lidocaine jelly applied over tracheal tube to reduce postoperative sore throat, cough and hoarseness of voice. $\mathrm{Br} \mathrm{J}$ Anaesth 2008:100:215-8

9. Kazemi A, Amini A. The effect of betamethasone gel in reducing sore throat, cough and hoarseness after laringotracheal intubation. Middle East $\mathrm{J}$ anesthesiol 2007:19:197-204

10. Darendorf H, Meltzer EO. Molecular and clinical pharmacology of intranasal corticosteroids: Clinical and Therapeutic implications. Allergy 2008:63:1292-300

11. Yao XL, Cowan MJ, Gladwin MT, Lawrence MM, Angus CW, Shelhamer JH. Dexamethasone alters arachidonats release from human epithelial cells by induction of $\mathrm{P} 11$ protein synthesis and inhibiting phospholipase A2 activity. J Biol Chem 1999: 274:17202-8

12. Stride PC. Postoperative sore throat: topical hydrocortisone. Anaesthesia 1990:45:968-71

13. Bagchi D, Mandal Mc, Das S, Sohoo T, Basu SR, Sakkar S. Efficacy of intravenous dexamethasone to reduce incidence of postoperative sore throat: A prospective randomized controlled trial. J Anaesthesiol Clin Pharmacol 2012:28:47780

14. Thomas S, Beevi S. Dexamethasone reduces the severity of postoperative sore throat. Can J anaesth 2007:54:897-901

15. Park SH, Han SH, Do SH, Kim JW, Rhee KJ, Kim JH. Prophylacticdexamethasone decrease the incidence of sore throat and hoarseness after tracheal extubation with a double lumen endotracheal tube. Anesth analg 2008; 107:1814-8

16. Ruangsin S, Wanasuwanakul T, Pattaravit $\mathrm{N}$, Asim W. Effectiveness of a preoperative single dose intravenous dexamethasone in reducing the prevalence of postoperative sore throat after endotracheal intubation. J Med Assoc Thai 2012;95:657-60 
17. Tabari M, Soltani G, Zirak N, Alipour M, Khazaeni K. Comparison of effectiveness of betamethasone gel applied to the tracheal tube and iv dexamethasone on postoperative sore throat: A randomized controlled trial. Iran J Otorhinolaringol. 2013;73:215-20

18. Kadri IA, Khazada TW, Samad A, Memon W. Post thyroidectomi sore throat: A common problem. Pak J Med Sci 2009:25:408:412

19. Eidi M, Sayedtoutounchi SJ, Kolahduzan K, Sadeghian P, Sayedtoutounchi N. Comparing the effect of dexamethasone before and after tracheal intubation on sore throat after tympanoplasty surgery: a randomized controlled trial. Iran J otorhinolaryngol 2014:26:89-98

20. Nurdin U, Lindholm CE, Wolgast $M$. Blood flow in the rabbit tracheal mucosa under normal conditions and under the influence of tracheal intubation. Acta anaesthesiol scand 1977:21:87-94

21. Roberson DP, Binshtok AM, Blasl F, Bean BP, Wolf CJ. Targeting of Sodium Channel Blockers into nociceptors to produce long duration analgesia. A systematic study and review. $\mathrm{Br} \mathrm{J}$ Pharmacol 2011;164:48-58

22. Newton DJ, Mc Leod GA, Khan F, Belch JJ. Mechanisms influencing the vasoactive effects of lidocaine in human skin. Anaesthesia 2007:62:146-50

23. Herlevsen P, Brehdal C, Hindsholm K, Kruhoffer PK. Prophylactic laringotracheal aerosolized lidocaine against postoperative sore throat. Acta
Anaesthesiol scand 1992; 36:505-7

24. Maruyama K, Sakai H, Miyazawa H, Iijima K, Toda N, Kawahara S, Hara K. Laryngotracheal application of lidocaine spray increases the incidence of postoperative sore throat after total intravenous anesthesia. J Anesth 2004:18:237-40

25. Hara K, Maruyama K. Effect of additive in lidocaine spray on post operative sore throat, hoarseness and dysphagia after total intravenous anesthesia. Acta anaesthesiol scand 2005:49:463-7

26. Doukumo DM, Faponle AF, Bolaji BO, Adenekan AT, Olateju SOA. Effect of lidocaine and K-Y jellies on sore throat, cough and hoarseness following endotracheal anaesthesia. J West Afr Coll Surg 2011 7;1:44-61

27. Navarro RM, Baugman VL. Lidocaine in the endotracheal tube cuff reduces postoperative sore throat. J Clin Anesth 1997:9:394-7

28. Huang CJ, Tsai MC, Chen CT, Cheng CR, $\mathrm{Wu} \mathrm{KH}$, Wei TT. In vitro diffusion of lidocaine across endotracheal cuff. Can J Anaesth 1999:46:82-6

29. Soltani HA, Aghadavoudi O. The effect of different lidocaine application methods on postoperative cough and sore throat. J Clin Anest 2002:14:15-8

30. Abbasi S, Mahjobipoor H, Sajedi P. The effect of lidocaine on reducing the tracheal mucosal damage following tracheal intubation. J Res Med Sci 2013:18:733738 